\title{
Production of exopolysaccharide by strains of Lactobacillus plantarum Y0175 and OF101 isolated from traditional fermented cereal beverage
}

\author{
Adekemi Titilayo Adesulu-Dahunsi ${ }^{\text {Corresp., }}{ }^{1}$, Kumaraswamy Jeyaram ${ }^{2}$, Abiodun Isiaka Sanni ${ }^{1}$, Kolawole Banwo ${ }^{1}$ \\ ${ }^{1}$ Department of Microbiology, University of Ibadan, Ibadan, Oyo, Nigeria \\ 2 Microbial Resource Division, Institute of Bioresources and Sustainable Development, Imphal, Manipur, India \\ Corresponding Author: Adekemi Titilayo Adesulu-Dahunsi \\ Email address: adesuluchemmy@yahoo.com \\ Lactobacillus plantarum Y0175 and OF101 isolates from Nigerian traditional fermented \\ cereal gruel 'ogi', were investigated on the basis of their capability to produce \\ exopolysaccharide (EPS) on sucrose modified deMan Rogosa Sharpe medium (mMRS). \\ Functional groups analysis of the EPSs produced (EPS-YO175 and EPS-OF101) by Fourier- \\ transform infrared (FT-IR) spectroscopy revealed the presence of $-\mathrm{OH}, \mathrm{C}=\mathrm{O}$ and $\mathrm{C}-\mathrm{H}$ \\ groups. The chemical composition of EPS-YO175 and EPS-OF101 showed the presence of \\ $87.1 \%$ and $80.62 \%$ carbohydrates and $1.21 \%$ and $1.47 \%$ protein. For maximum EPS yield, \\ three significant factors were optimized using central composite design and response \\ surface methodology, the predicted maximum EPS produced was $1.38 \mathrm{~g} / \mathrm{L}$ and $2.19 \mathrm{~g} / \mathrm{L}$, \\ while the experimental values were $1.36 \mathrm{~g} / \mathrm{L}$ and $2.18 \mathrm{~g} / \mathrm{L}$ for EPS-YO175 and EPS-OF101. \\ The EPS samples showed strong antioxidant activities in-vitro. The scale-up of the \\ production process of the EPS will find its potential application in food industries.
}




\section{Article Title}

2 Production of exopolysaccharide by strains of Lactobacillus plantarum YO175 and OF101

3 isolated from traditional fermented cereal beverage

\section{Authors}

6 Adekemi Titilayo Adesulu-Dahunsi

7 Kumaraswamy Jeyaram

8 Abiodun Isiaka Sanni

9 Kolawole Banwo

\section{Affiliations}

Adekemi T. Adesulu-Dahunsi

Kumaraswamy Jeyaram

Abiodun I. Sanni

1. Microbial Resources Division, Institute of Bioresources and Sustainable Development (IBSD), Imphal-795001, Manipur, India.

Kolawole Banwo

1. Department of Microbiology, University of Ibadan, Ibadan, Oyo State, Nigeria.

\section{Corresponding Author}

adesuluchemmy@yahoo.com 


\section{Production of exopolysaccharide by strains of Lactobacillus plantarum YO175 and OF101 isolated from traditional fermented cereal beverage.}

\section{Abstract.}

Lactobacillus plantarum YO175 and OF101 isolates from Nigerian traditional fermented cereal gruel 'ogi', were investigated on the basis of their capability to produce exopolysaccharide (EPS) on sucrose modified deMan Rogosa Sharpe medium (mMRS). Functional groups analysis of the EPSs produced (EPS-YO175 and EPS-OF101) by Fourier-transform infrared (FT-IR) spectroscopy revealed the presence of $-\mathrm{OH}, \mathrm{C}=\mathrm{O}$ and $\mathrm{C}-\mathrm{H}$ groups. The chemical composition of EPS-YO175 and EPS-OF101 showed the presence of $87.1 \%$ and $80.62 \%$ carbohydrates and $1.21 \%$ and $1.47 \%$ protein. For maximum EPS yield, three significant factors were optimized using central composite design and response surface methodology, the predicted maximum EPS produced was $1.38 \mathrm{~g} / \mathrm{L}$ and $2.19 \mathrm{~g} / \mathrm{L}$, while the experimental values were $1.36 \mathrm{~g} / \mathrm{L}$ and $2.18 \mathrm{~g} / \mathrm{L}$ for EPS-YO175 and EPS-OF101. The EPS samples showed strong antioxidant activities in-vitro. The scale-up of the production process of the EPS will find its potential application in food industries.

\section{Introduction.}

The ability of various lactic acid bacteria (LAB) to produce extracellular long-chain polysaccharides/exopolysaccharides which consists of branched and repeating units of sugars in varied ratios have been reported (Pan \& Mei, 2010; Wang et al., 2010; Li et al., 2014; Imran et al., 2016). The EPS produced have immense commercial importance because of the industrially beneficial physico-chemical properties they exhibit and GRAS (generally recognized as safe) status of the LAB from which they are secreted (Surayot et al., 2014). Exopolysaccharide produced by LAB play essential roles in improving the mouth feel, texture, and rheology of fermented food preparations. They also serve as food additives, prebiotics and demonstrate useful physiological effects such as anticarcinogenecity, antitumor, immunomodulating activities and as blood cholesterol-lowering agent in humans (Kim et al., 2010).

Many indigenous foods produced in Nigeria are usually fermented before consumption (Adesulu \& Awojobi, 2014). Lactic acid bacteria are commonly isolated from Nigerian indigenous fermented foods and beverages (Banwo, Sanni \& Tan, 2013; Sanni \&Adesulu, 2013; Adesulu- 
63 Dahunsi, Sanni \&Jeyaram, 2017a). Ogi is a popular non-alcoholic fermented cereal beverage that 64 is processed by natural fermentation with the dominance of LAB. It forms staple food of the 65 people in West Africa, especially among the south-western Nigerian where it serves as weaning 66 food in infants and/or breakfast beverage among the adults. Exopolysaccharides produced by 67 some of the LAB isolated from these fermented food products have been documented to improve 68 the food texture and quality. Exopolysaccharides producing LAB such as Streptococcus thermophilus, Lactobacillus delbrueckii subsp. bulgaricus, Lactococcus lactis subsp. cremoris isolated from dairy products and fermented milk have been extensively studied (Patel \& Prajapati, 2013).

Different species of LAB, especially Lactobacillus plantarum have been reported to produce EPS (Wang et al., 2010; Imran et al., 2016). L. plantarum perform important fermentative roles during Nigerian traditional food preparation and provides positive health impacts which are strain specific, they exhibit an outstanding effect on the flavour and texture of these foods, with specific metabolic and technological properties, such as production of EPS (Adesulu-Dahunsi et al., 2017b). Recently, researchers have reported that EPS produced from LAB species have antioxidant activities and are non-toxic; these characteristics are of great importance and may replace the synthetic antioxidants (Li et al., 2013; Zhang et al., 2013; Abdhul, et al., 2014). Exopolysaccharides produced by Lactobacillus species improves sourdough properties by aiding water absorption, improving its structure, thereby prolonging shelf life of the fermented foods. Few works have been reported on EPS producing ability of LAB strains isolated from cerealsbased fermented food (Torres-Rodríguez et al., 2014; Adesulu-Dahunsi et al., 2018a, 2018b).

84 Optimization of the growth factors and media composition are criteria to be considered for maximal EPSs production by LAB strains (Zajseket, Gorsek \&Kolar, 2013, Adesulu-Dahunsi et 
86 al., 2018c). The statistical designs used in this study to determine the optimal conditions for the

87 EPS production are central composite design (CCD) and response surface methodology (RSM).

88 The objective of this study was to improve the production of EPS from L. plantarum strains and

89 to evaluate the antioxidant activities in vitro. The factors affecting the production of EPS from $L$.

90 plantarum YO175 and OF101 were analyzed, and three significant variables (cultivation time, $\mathrm{pH}$

91 and sucrose concentration) were chosen to optimize the production conditions using CCD and

92 RSM. In addition, the in vitro antioxidant assays of the EPS were also evaluated.

93 Materials and methods

94 Microorganisms and chemicals

95 Two EPS-producing LAB strains isolated from ogi (Nigerian indigenous fermented cereal gruel

96 from yellow and white maize varieties) were identified according to their biochemical

97 characteristics and 16S rRNA gene sequencing as L. plantarum YO175 and L. plantarum OF101

98 (GenBank Accession numbers KU892395 and KU892393). DPPH, trichloroacetic acid (TCA),

99 trifluoroacetic acid (TFA), Folin-Ciocalteu reagent, bovine serum albumin (BSA), phenol, 100 concentrated sulfuric acid, methanol, ferric chloride, potassium ferric cyanide, pyrogallol, 101 ascorbic acid, glucose, galactose, rhamnose, xylose, fructose and ribose (Sigma chemical ltd., St. 102 Louis, USA).

103 Extraction and purification of EPS

104 The isolation and partial purification of the EPS samples were performed as previously described 105 by Savadogo et al. (2004), and modified by Adesulu-Dahunsi et al. (2018a) with mMRS broth as 106 the cultivation medium as it support the growth of L. plantarum species and MRS as growth 107 medium for all LAB species. Briefly, L. plantarum YO175 and L. plantarum OF101 were 108 propagated in $1000 \mathrm{~mL}$ MRS modified sucrose broth (glucose was replaced with sucrose) and 
109 incubated for $24 \mathrm{~h}$ in an incubator shaker, the L. plantarum cultures were heated at $100^{\circ} \mathrm{C}$ for 10 $110 \mathrm{~min}$, then centrifuged at $12,000 \mathrm{xg}$ for $15 \mathrm{~min}$ to remove the cells, the supernatants was

111 precipitated with double volume ice-cold ethanol, shaken vigorously and centrifuged at 5,000 xg

112 for $30 \mathrm{~min}$ at $4^{\circ} \mathrm{C}$. The pellets obtained were dried to a constant weight in an oven at $50^{\circ} \mathrm{C}$. The

113 resulting pellets were mixed with ultrapure water, the EPS slurry was precipitated with double

114 volume of cold ethanol, this step was repeated three times in order to eliminate any cells debris

115 that may be present. The EPS was mixed with minimal water and dialyzed against distilled water

116 using $10 \mathrm{kDa}$ membranes for $48 \mathrm{~h}$ at $4{ }^{\circ} \mathrm{C}$ with the changing of the water twice daily. The 117 partially purified EPS obtained from dialysis was frozen at $-20^{\circ} \mathrm{C}$ in deep freezer. The frozen

118 EPS was covered with parafilm and were lyophilized for 2 days and the resulting EPS samples

119 were preserved for further characterization.

\section{Molecular mass determination}

121 The molecular mass of the EPS-YO175 and EPS-OF101 were determined on an Agilent

122 1100HPLC system equipped with a TSK-GEL G3000SWxl column (7.5 x $300 \mathrm{~mm}$, Tosoh

123 Corp., Tokyo, Japan) and a refractive index detector (RID). The column was eluted with $0.1 \mathrm{M}$

$124 \mathrm{Na}_{2} \mathrm{SO}_{4}$ solution at a flow rate of $0.8 \mathrm{~mL} \min ^{-1}$. Molecular mass was estimated from the standard 125 graph which was plotted using standard dextrans (Sigma-Aldrich, USA) (Pan \& Mei, 2010).

126 Chemical composition analysis

127 Total carbohydrate, total soluble protein content of the EPS samples, and lactic acid (LA)

128 produced by the L. plantarum strains were determined.

129 The EPS samples were estimated using phenol-sulphuric acid method (Dubois et al., 1956). To 1 $130 \mathrm{ml}$ of $5 \%$ cold phenol and $5 \mathrm{~mL}$ concentrated sulphuric acid placed in an ice bath, $1 \mathrm{~mL}$ of the 
131 EPS sample were added, then incubated at room temperature for $20 \mathrm{~min}$ and the absorbance of

132 the samples at $490 \mathrm{~nm}$ was taken using spectrophotometer.

133 Estimation of the protein content was performed according to Lowry, Rosebrough \& Randall, 134 (1951). To $1 \mathrm{~mL}$ EPS sample (s), $5 \mathrm{~mL}\left(2 \% \mathrm{Na}_{2} \mathrm{CO}_{3}\right.$ in $0.1 \mathrm{~N} \mathrm{NaOH}$ and $0.5 \% \mathrm{CuSO}_{4}$ in $1 \%$ 135 potassium sodium tartrate in 50:1) was added and vortexed. The mixture was incubated at 136 ambient temperature for $10 \mathrm{~min}, 0.5 \mathrm{~mL} 1 \mathrm{~N}$ Folin-Ciocalteau reagent was added and mixed and 137 was kept in dark for 20 min after which the colour was measured at $660 \mathrm{~nm}$.

138 The production of LA in MRS broth by the L. plantarum strains was estimated. To $1 \mathrm{~mL}$ of the 139 culture supernatants, $0.05 \mathrm{~mL}$ of $4 \% \mathrm{CuSO}_{4}$ and $6 \mathrm{~mL}$ of concentrated sulphuric acid was added and mixed well. The mixture was then incubated in boiling water bath for $10 \mathrm{~min}, 100 \mu \mathrm{L}$ of $\mathrm{p}$ -

141 hydroxydiphenyl was added and kept in room temperature for $30 \mathrm{~min}$. The absorbance was 142 measured at 560nm (Salvucci, LeBlanc \& Perez, 2016).

\section{Analysis of monosaccharide composition}

144 The monosaccharide composition of the purified EPS samples was determined by thin layer chromatography (TLC) via aluminum plates coated with silica gel and high-performance liquid chromatography (HPLC) after hydrolysis of the EPS. Five milligram (5mg) of the purified EPS sample (s) was dissolved in $0.5 \mathrm{~mL}$ MilliQ water and hydrolyzed in $0.5 \mathrm{~mL}$ of $6 \mathrm{~N}$ trifluoroacetic acid (TFA) at $100^{\circ} \mathrm{C}$ for $3 \mathrm{~h}$. The hydrolysate was evaporated to dryness at $50^{\circ} \mathrm{C}$. Five microlitres $(5 \mu \mathrm{L})$ of the EPS samples were spotted onto a silica gel coated aluminum TLC plates. The mixed solvent ( $\mathrm{n}$ - butanol, ethanol, and water $(50: 30: 20 \mathrm{v} / \mathrm{v} / \mathrm{v})$ were used for separation of carbohydrates and standards, the fractions were visualized on the TLC plates, after dipping it in anisaldehyde-sulphuric acid reagent and heating the plates at $110^{\circ} \mathrm{C}$ for $30 \mathrm{~min}$. The EPS was

153 also analyzed with HPLC system (Agilent 1100) equipped with Aqueous GPC start up Kit 
154 column and eluted with distilled water at a flow rate of $1.0 \mathrm{~mL} / \mathrm{min}$ at $20^{\circ} \mathrm{C}$. The separated

155 components were monitored by a refractive index detector.

156 Analysis of functional groups

157 The infrared analysis of purified EPS from the two L. plantarum strains was carried out using an

158 FT-IR spectrophotometer (Thermo Nicolet, USA) in the spectrum ranges of $400-4000 \mathrm{~cm}^{-1}$ for

159 the detection of functional groups present in the samples.

\section{Preliminary screening of cultivation condition and media composition for EPS production}

161 The optimal media composition and cultivation condition for EPS production in MRS broth were

162 screened. The media components, carbon source $(20 \mathrm{~g} / \mathrm{L})$, organic nitrogen sources $(25 \mathrm{~g} / \mathrm{L})$, 163 inorganic nitrogen sources $(2 \mathrm{~g} / \mathrm{L})$, were substituted independently into the media and by keeping

164 other component constant at different cultivation time $(12,24,36,48,60,72,84$ and $96 \mathrm{hr})$, 165 initial $\mathrm{pH}$ of the media $(6,6.5,7,8)$ and different temperatures $\left(20,25,30,37\right.$ and $\left.45^{\circ} \mathrm{C}\right)$.

\section{In vitro determination of antioxidant properties}

167 The in-vitro antioxidant properties of the purified EPS samples (at $0.5-4 \mathrm{mg} / \mathrm{mL}$ concentration 168 levels) were performed using standard methods.

169 The DPPH (1,1-diphenyl-2-picryl-hydrazyl) radical scavenging was measured according to the 170 method of Rai et al. (2011). To 1.0 mL EPS samples, $2.0 \mathrm{~mL}$ deionized water and $2.0 \mathrm{~mL} \mathrm{DPPH}$ 171 solution $(0.16 \mathrm{mM})$ were added, the mixture were incubated at $37^{\circ} \mathrm{C}$ in a dark room for $30 \mathrm{~min}$.

172 Absorbance (at $517 \mathrm{~nm}$ ) was measured against the blank. For the positive control, methanol was 173 replaced with DPPH.

174 The DPPH radical (\%) scavenging activity $=1-(\mathrm{As}-\mathrm{Ab}) / \mathrm{Ac} \times 100$

175 As = Absorbance of the EPS sample (s)

$176 \mathrm{Ab}=$ Absorbance of blank

$177 \mathrm{Ac}=$ Absorbance of control 
178 Superoxide scavenging activity of the EPS samples was performed according to Balakrishnan et

179 al. (2011) published protocol. The mixture contained $0.3 \mathrm{~mL}$ of the EPS samples, $2.6 \mathrm{~mL}$ (50 $180 \mathrm{mM}$ ) phosphate buffer at $\mathrm{pH} 8.2$ and $90 \mu \mathrm{L}$ of $3 \mathrm{mM}$ pyrogallol (dissolved in $10 \mathrm{mM} \mathrm{HCl}$ ). Then 181 the absorbance (at $325 \mathrm{~nm}$ ) was taken at $0 \mathrm{~min}$ and $10 \mathrm{~min}$.

182 Superoxide scavenging activity $(\%)=1-\left(\mathrm{A}_{10}-\mathrm{A}_{0}\right) /\left(\mathrm{C}_{10}-\mathrm{C}_{0}\right) \times 100$

$183 \mathrm{~A}_{0}$ absorbance of EPS sample (s) at 0 min

$184 \mathrm{~A}_{10}$ absorbance of EPS sample (s) at $10 \mathrm{~min}$

$185 \mathrm{C}_{0}$ absorbance of control at $0 \mathrm{~min}$

$186 \mathrm{C}_{10}$ absorbance of control at $10 \mathrm{~min}$

187 To measure the reducing power potential of the EPS samples, the following mixture; $100 \mu \mathrm{L}$ of 188 the EPS sample, $900 \mu \mathrm{L}$ of phosphate buffer $(0.2 \mathrm{M}, \mathrm{pH} 6.6)$ and $900 \mu \mathrm{L}$ of $1 \%$ potassium ferric 189 cyanide were incubated at $50^{\circ} \mathrm{C}$ for $20 \mathrm{~min}$. Nine hundred microliter of TCA (10\%) was mixed 190 with the solution and centrifuged at $5000 \mathrm{x}$ g for $15 \mathrm{~min}$, then $900 \mu \mathrm{L}$ each of the supernatant 191 solution, distilled water and $0.1 \%$ ferric chloride were mixed together. The solution mixed 192 together and the absorbance $(700 \mathrm{~nm})$ was taken (Balakrishnan et al., 2011).

193 The hydroxyl radical scavenging activity of the EPS samples was measured with the Fenton 194 reaction. One milliliter $(1 \mathrm{~mL})$ of the EPS samples was added to the reaction mixture containing $1951.0 \mathrm{~mL}$ of brilliant green $(0.435 \mathrm{mM}), 2.0 \mathrm{~mL}$ of $\mathrm{FeSO}_{4}(0.5 \mathrm{mM})$ and $1.5 \mathrm{~mL}$ of $\mathrm{H}_{2} \mathrm{O}_{2}(3.0 \%$, $196 \mathrm{w} / \mathrm{v}$ ) and was incubated at $37^{\circ} \mathrm{C}$ for $20 \mathrm{~min}$, and the absorbance (at $624 \mathrm{~nm}$ ) was then measured 197 (Balakrishnanet al., 2011).

198 The hydroxyl radical scavenging activity $(\%)=\left(\mathrm{As}-\mathrm{A}_{0}\right) /\left(\mathrm{A}-\mathrm{A}_{0}\right) \times 100$

$199 \quad A_{\mathrm{S}}=$ Absorbance of the sample

$200 \mathrm{~A}_{0}=$ Absorbance of the control

$201 \mathrm{~A}=$ Absorbance of deionized water without the sample and Fenton reaction 
203 Statistical analysis

204 All experiments were performed in triplicates and the results represented by their mean \pm SD.

205 Tests of significant differences were determined by Duncan's Multiple Range Test at $(\mathrm{P}<0.05)$.

206 For maximum EPS production, Design-Expert software version 8.0.7.1 (Stat-Ease Inc., 207 Minneapolis, USA) used for the experimental designs and regression analysis of the 208 experimental data. Statistical analysis of the model was performed to evaluate the analysis of 209 variance (ANOVA) and and its statistical significance was determined by F-test.

\section{Results}

212

213

214

215

216

217

218

219

220

221

222 The TLC analysis of the EPS samples was compared with the sugar standards, and their retention 223 224

\section{Molecular mass of the EPS}

Based on the calibration curve of the elution retention time of various dextran standards used, the molecular mass of EPS-YO175 and EPS-OF101 was estimated to be $1.2 \times 10^{6}$ Da and $4.4 \times 10^{5}$ Da.

\section{Chemical composition analysis of the EPS}

Total carbohydrate content in EPS-YO175 was $87.1 \%$ and $80.62 \%$ for EPS-OF101. The total soluble protein showed low protein content of approximately 1.21\% and 1.47\% for EPS-YO175 and EPS-OF101. The lactic acid produced by L. plantarum YO175 and OF101 was $13.6 \pm 0.1$ $\mathrm{mg} / \mathrm{mL}$ and $11.4 \pm 0.15 \mathrm{mg} / \mathrm{mL}$, respectively.

\section{Analysis of monosaccharide composition} time values revealed that EPS-YO175 composed of glucose and galactose and EPS-OF101 showed only glucose (Figure S1 of Supplementary material). 
225 The retention time of the EPS samples was compared with the reference standards in the HPLC

226 analysis; this also confirmed that the EPS samples contained glucose and galactose (Figure 1).

227 Analysis of functional groups of the EPS

228 The FTIR spectrum of the EPS samples revealed that the polysaccharides contained significant

229 number of O-H group representing vibration of the hydroxyl groups of carbohydrate showed by

230 broad stretching in the region $3288 \mathrm{~cm}^{-1}$ and $3276 \mathrm{~cm}^{-1}$. The stretching bands around the 2924

$231 \mathrm{~cm}^{-1}$ and $2898 \mathrm{~cm}^{-1}$ region were due to $\mathrm{C}-\mathrm{H}$ stretching vibration. The absorptions around 1655

$232 \mathrm{~cm}^{-1}$ and $1649 \mathrm{~cm}^{-1}$ were due to stretching vibration of carbonyl group $(\mathrm{C}=\mathrm{O})$. The bands

233 observed around $1159 \mathrm{~cm}^{-1}$ in EPS-YO175 and $1150 \mathrm{~cm}^{-1}$ in EPS-OF101 were attributed to the

234 vibration of C-O-C bond (Figure 2).

235

236

237

238

239

240

241

242

243

244

245

246

247

\section{Preliminary screening of cultivation condition and media composition}

Among the different carbon sources, the highest EPS yield was obtained for the sucrose supplemented MRS broth in L. plantarum YO175 $(1.59 \pm 0.06 \mathrm{~g} / \mathrm{L})$ and OF101 $(1.07 \pm 0.01 \mathrm{~g} / \mathrm{L})$. Also at $20 \mathrm{~g} / \mathrm{L}$ sucrose concentration, the EPS yield obtained for both L. plantarum strains were; $1.64 \pm 0.11$ and $1.05 \pm 0.02 \mathrm{~g} / \mathrm{L}$ respectively. Yeast extract was the most effective among the nitrogen sources screened, as the optimal EPS yield obtained were $1.63 \pm 0.05 \mathrm{~g} / \mathrm{L}$ and $1.01 \pm$ $0.02 \mathrm{~g} / \mathrm{L}$ in L. plantarum YO175 and OF101. Ammonium sulphate showed optimal EPS yield in both strain; L. plantarum YO175 $(1.56 \pm 0.02 \mathrm{~g} / \mathrm{L})$ and OF101 $(1.00 \pm 0.02 \mathrm{~g} / \mathrm{L})$. The optimal temperature and $\mathrm{pH}$ for the EPS production was $30^{\circ} \mathrm{C}$ and $\mathrm{pH} 7.0$ respectively with the corresponding EPS $(\mathrm{g} / \mathrm{L})$ yield $(1.56,1.03$; and $1.72 ; 1.10)$ (Table 1). The dry EPS samples are shown in Figure S2 of Supplementary material. 


\section{Response surface optimization for enhanced EPS production}

249 A design model with 20 runs in 1 block was performed and the variables were tested at four

250 levels (Tables 2A \& 2B). The statistical significance of the experimental data was checked using

251 Fischer's statistical test for ANOVA, the 3D graphs were also designed. Table 3A \& 3B showed

252 that the model p-values of 0.0053 and 0.0010 for EPS-YO175 and EPS-OF101 were significant.

253 Also, the Model F-values of 5.88 and 8.88 for EPS-YO175 and EPS-OF101 imply that the

254 models were significant. In EPS-YO15 and EPS-OF101, the lack-of-fit term was greater than

2550.05 which is non- significant relative to the pure error.

256 The developed regression model equations describing the relationship between the EPS yield (Y)

257 and the coded values of independent factors; cultivation time (hr) (A), sucrose concentration (g)

258 (B), $\mathrm{pH}(\mathrm{C})$ and their corresponding interactions is described below:

259

260

261

262

263

264

265

266

$\begin{aligned} \mathrm{Y}_{\mathrm{EPS}-\mathrm{YO} 175}= & 2.15+5.891 \mathrm{E}-003 \mathrm{~A}+0.011 \mathrm{~B}-7.356 \mathrm{E}-003 \mathrm{C}-3.750 \mathrm{E} \\ & -003 \mathrm{AB}+0.011 \mathrm{AC}+6.250 \mathrm{E}-003 \mathrm{BC}-0.013 \mathrm{~A}^{2}-0.011 \mathrm{~B}^{2}\end{aligned}$

$-0.013 C^{2}$

Eq. A.1

$\mathrm{Y}_{\text {EPS-OF101 }}=1.35-0.018 \mathrm{~A}+0.027 \mathrm{~B}+0.019 \mathrm{C}+0.019 \mathrm{AB}+6.250 \mathrm{E}$

$-003 \mathrm{AC}-0.011 \mathrm{~B}-0.017 \mathrm{~A}^{2}-0.074 \mathrm{~B}^{2}-4.874 \mathrm{E}-003 \mathrm{C}^{2}$

Eq. A.2

where Y implies EPS yield (g/L).

267 Three-dimensional response surface plots and contour of EPS yield from L.plantarum YO175

268 (Figure 3A-C) and OF101 (Figure 4A-C) illustrate the interactions between the three variables.

269 The curvatures' nature of 3D surfaces gave good interaction between sucrose concentration and

270 cultivation time, $\mathrm{pH}$ and cultivation time, $\mathrm{pH}$ and sucrose concentration.

271 The optimal values of the independent factors selected for the production of EPS were obtained

272 by solving the regression equation (Eq.A1-A2) using the Expert Design 8.0.7.1 software

273 package. The optimal values of the tested variables of L. plantarum YO175 were; cultivation

274 time, $48.50 \mathrm{hr}$; sucrose concentration, $23.00 \mathrm{~g} / \mathrm{L}$, and $\mathrm{pH}, 7.40$. Under these conditions, the 
275 maximum predicted yield of EPS was $1.38 \mathrm{~g} / \mathrm{L}$ and its experimental yield was $1.36 \mathrm{~g} / \mathrm{L}$. For $L$.

276 plantarum OF101, the optimal values of the test variables were; cultivation time, $48.00 \mathrm{hr}$;

277 sucrose concentration, $23.50 \mathrm{~g} / \mathrm{L}$ and $\mathrm{pH}, 7.50$ and the maximum predicted yield was $2.19 \mathrm{~g} / \mathrm{L}$

278 and its actual experimental value was $2.18 \mathrm{~g} / \mathrm{L}$.

279 In vitro determination of antioxidant properties

280 DPPH free radical scavenging activity

281 The DPPH scavenging activity observed in the EPS samples and ascorbic acid at concentration

282 of $0.5 \mathrm{mg} / \mathrm{mL}$ was lower than the ones at $4 \mathrm{mg} / \mathrm{mL}$. At $4 \mathrm{mg} / \mathrm{mL}$, the scavenging activity for the

283 ascorbic acid was significantly higher than those found in L. plantarum YO175 (56.9\%) and

284 OF101 (51.2\%) respectively (Table 4).

285 Superoxide scavenging activity

286 The superoxide scavenging activity of purified EPS samples and ascorbic acid are shown in

287 Table 4 . As the concentration increases from $0.5 \mathrm{mg} / \mathrm{mL}$ to $4 \mathrm{mg} / \mathrm{mL}$ the scavenging effects also 288 increases; from $23 \%-45.3 \%$ in EPS-OF101, 37.9\%-83.1\% in ascorbic acid and 43.2\%-89.4\% 289 in EPS-YO175.

\section{Reducing power activity of EPS}

291 The reducing power of the EPS sample (s) and ascorbic acid increased with the increase in the 292 concentration levels from $0.5 \mathrm{mg} / \mathrm{mL}$ to $4 \mathrm{mg} / \mathrm{mL}$. The reducing power of the ascorbic acid, 293 EPS-YO175 and EPS-OF101 at $4 \mathrm{mg} / \mathrm{mL}$ concentration are; $(0.91>0.41>0.34)$, no significant 294 differences was observed between the EPS samples, but the result obtained for the ascorbic acid 295 showed that there was significance different from the EPS-YO175 and OF101 (Table 4). 296 


\section{Hydroxyl radical scavenging activity}

299 The hydroxyl radical generated by the Fenton reaction in the system, was scavenged by the EPS-

300 YO175, EPS-OF101 and ascorbic acid. Their scavenging effects are shown in Table 4. The two

301 EPS samples exhibited moderate scavenging effect against hydroxyl radical, and EPS-YO175

302 showing stronger scavenging effect than EPS-OF101. However, ascorbic acid showed higher

303 hydroxyl radical scavenging activity and was significantly different from the EPS samples. At a

304 concentration of $4 \mathrm{mg} / \mathrm{mL}$, the scavenging activity for EPS-YO175, EPS-101, and ascorbic acid

305 was $66.0 \%, 52.3 \%$ and $83.1 \%$ respectively.

\section{Discussion}

307 Exopolysaccharides produced by strains of Lactobacillus plantarum YO175 and OF101 isolated 308 from traditional fermented cereal beverage on MRS sucrose modified media were investigated.

309 The chemical composition analysis showed that EPS samples contained significant amount of 310 carbohydrate content and relatively low protein. High carbohydrate content from LAB-EPS has

311 been documented by several researchers (Li et al 2014; Wang et al., 2015; Imran et al., 2016).

312 Liu et al. (2002) also reported protein content as low as $2.3 \%$ from EPS obtained from the 313 fermentation of kefir grains. Lactic acid is the major metabolic end product of carbohydrate 314 fermentation in LAB. These LAB strains were found to produce LA, and therefore they possess 315 the ability to lower $\mathrm{pH}$ in food which may results in the development of desirable organoleptic 316 properties and inhibition of the pathogenic microorganisms in food, thereby ensuring safety and 317 stability of the final product.

318 The analysis of the EPS monosaccharide composition revealed glucose and galactose monomers, 319 which indicates that EPS-YO175 is an heteropolysaccharide and EPS-OF101 is an 320 homopolysaccharide. Our result is in agreement with Imran et al. (2016) who reported that the 
321 monomer composition in EPS samples can vary among different strains of the same species.

322 Tallon, Bressollier \& Urdaci (2003) reported that L. plantarum EP56 is composed of glucose and

323 galactose. Other researchers have also reported that EPS from L. plantarum are composed of

324 different sugar moieties (Ismail \& Nampoothiri, 2010; Imran et al., 2016).

325 FT-IR is a useful tool for determining the functional groups in EPS (Wang et al., 2008). The

326 functional groups present in the two EPS samples as determined by FT-IR spectral analysis

327 showed absorption bands of polymeric structure(s). The functional groups with the vibration

328 frequencies when compared with the FT-IR spectra analysis of the other polysaccharides

329 reported in the literature confirmed that the two EPS samples are carbohydrates (Wang et al.,

330 2010). Similar FTIR peak range was observed for L.plantarum YW11 isolated from Tibet kefir

331 and L. helveticus MB2-1 isolated from say ram ropy fermented milk (Li et al., 2014; Wang et al.,

332 2015).

333 The amounts of EPS produced by microorganisms depend solely on the cultivation conditions

334 and media composition (Wang et al., 2010). Carbon and nitrogen sources, cultivation time,

335 temperature and $\mathrm{pH}$ have been reported to influence growth and production of EPS by LAB

336 (Gandhi, Rayand \& Patel, 1997). Ismail \& Nampoothri, (2010) and Kanmani et al. (2011)

337 reported that at $35^{\circ} \mathrm{C}$ and $\mathrm{pH}$ ranging between 6.5 and 7.0 , maximum EPS production was 338 obtained for the EPS producing Lactobacillus and Streptococcus species. The optimum range of

339 cultivation conditions obtained during the production of EPS was similar to those reported by

340 other researchers (Hallemeersch, De Baet \& Vandamme, 2002; Sarwat, Aman \& Ahmed, 2008;

341 Wang et al., 2015; Adesulu-Dahunsi, Sanni \& Jeyaram, 2018b). The presence of growth factors

342 such as large quantities of amino acids and short peptides in the yeast extract resulted to enhance

343 EPS production. Liu et al. (2009) also observed that in the presence of yeast extract, high EPS 
344 was produced by Paenibacillus polymyca EJS-3. The response surface optimization for enhanced

345 EPS production using RSM and CCD gave good agreement between the experimental and

346 predicted values. This implied that the mathematical models were suitable for the simulation of

347 EPS production in the present study. Many researchers have reported varied amount of EPS

348 produced by Lactobacillus plantarum species (Zhang et al., 2013; Li et al., 2014).

349 The in vitro determination of the antioxidant activities increased with increase in their 350 concentrations, no significant difference was observed between the EPS samples. Also, the The 351 activities increased in dose dependent manner as the EPS concentrations, ascorbic acid was 352 found to have higher antioxidant activities when compared with the two EPS samples. The 353 antioxidant potentials displayed by the EPS samples in this study was similar to those reported 354 by other researchers (Sun et al., 2012; Ye et al., 2012; Zhang et al., 2013).

\section{Conclusion}

356 In the present work, the optimization of growth parameters using statistical methodology both 357 CCD and RSM for enhanced EPS production by L. plantarum strains (YO175 and OF101) 358 isolated from ogi, Nigerian indigenous fermented food was studied. The in vitro antioxidant 359 assays showed that the EPS produced by the two L. plantarum strains have strong antioxidant potentials. These characteristics of the EPS produced would make it a promising candidate for its exploitation in food industry.

\section{References}

Abdhul K, Ganesha M, Shanmughapriya S, Kanagavel M, Anbarasu K, Natarajaseenivasana K. 2014. Antioxidant activity of exopolysaccharide from probiotic strain Enterococcus faecium (BDU7) from Ngari. International Journal of Biological Macromolecules 70: 450-454. 
367 Adesulu AT, Awojobi KO. 2014. Enhancing sustainable development through indigenous

368 fermented food products in Nigeria. African Journal of Microbiology Research 8: 1338-1343.

369 Adesulu-Dahunsi AT, Sanni AI, Jeyaram K. 2017a. Rapid differentiation among Lactobacillus,

370 Pediococcus and Weissella species from some Nigerian indigenous fermented foods, $L W T$ -

371 Food Science and Technology 77: 39-44.

372 Adesulu-Dahunsi AT, Sanni AI, Jeyaram K, Banwo K. 2017b. Genetic diversity of Lactobacillus

373 plantarum strains from some indigenous fermented foods in Nigeria. LWT-Food Science and

374 Technology 82:199-206.

375 Adesulu-Dahunsi AT, Sanni AI, Jeyaram, K, Ojediran JO, Ogunsakin AO,Banwo K. 376 2018a.Extracellular polysaccharide from Weissella confusa OF126: Production, optimization, 377 and characterization. International Journal of Biological Macromolecules 111: 514-525.

378 Adesulu-Dahunsi AT, Jeyaram K and Sanni AI. 2018b. Probiotic and technological properties of 379 exopolysaccharide producing Lactic acid bacteria isolated from some cereal-based Nigerian 380 indigenous fermented food products. Journal of Food Control 92:225-231.

381 Adesulu-Dahunsi AT, Sanni AI, Jeyaram K.2018c. Production, characterization and In vitro 382 antioxidant activities of exopolysaccharide from Weissella cibaria GA44. LWT-Food Science 383 and Technology 87: 432-442.

Balakrishnan B, Prasad B, Rai AK, Velappan SP, Subbanna MN, Narayan B. 2011. In-vitro 385 antioxidant and antibacterial properties of hydrolyzed proteins of delimed tannery fleshings: 386 Comparison of acid hydrolysis and fermentation methods. Biodegradation 22:287-295. 
387 Banwo K, Sanni A, Tan H. 2013.Technological properties and probiotic potential of 388 Enterococcus faecium strains isolated from cow milk. Journal of Applied Microbiology 114:229389241.

390 Dubois M, Gilles K, Hamilton J, Rebers P. Smith F. 1956.Colorimetric methods for 391 determination of sugars and related substances. Annals of Chemistry 28: 350-356.

392 Gandhi HP, Rayand RM, Patel RM. 1997. Exopolymer production by Bacillus species. 393 Carbohydrate Polymers 34: 323-327.

394 Hallemeersch I, De Baet S, Vandamme EJ. 2002. Exopolysaccharides of lactic acid 395 bacteria. Biopolymer, Wiley VCH: Weinheim. pp. 407-29.

396 Imran MYM, Reehana N, Jayaraj KA, Ahamed AZP, Dhanasekarana D, Thajuddina N, Alharbic 397 NS, Muralitharana G. 2016. Statistical optimization of exopolysaccharide production by 398 Lactobacillus plantarum NTMI05 and NTMI20. International Journal of Biological 399 Macromolecules 93:731-745.

400 Ismail B, Nampoothiri KM. 2010. Production, purification and structural characterization of an 401 exopolysaccharide produced by a probiotic Lactobacillus plantarum MTCC 9510. Archive of 402 Microbiology 192:1049-1057.

403 Kim Y, Oh S, Yun HS, Kim SH. 2010. Cell-bound exopolysaccharide from probiotic bacteria 404 induces autophagic cell death of tumour cells. Letters in Applied Microbiology 51: 123-130. 
405 Li W, Ji J, Rui X, Yu J, Tang W, Chen X, Jiang M, Dong M. 2014. Production of 406 exopolysaccharides by Lactobacillus helveticus MB2-1 and its functional characteristics in vitro. 407 LWT - Food Science and Technology 59:732-739.

408 Li Z,Jiang A,Yue T,Wang J,Wang Y,Su J. 2013. Purification and identification of five novel 409 antioxidant peptides from goat milk casein hydrolysates, Journal of Dairy Science 96: 42424104251.

411 Liu JR, Wang SY, Lin YY, Lin CW. 2002. Antitumor activity of milk, kefir and soya milk kefir 412 in tumor bearing mice. Nutrition and Cancer 44: 183-187.

413 Lowry OH, Rosebrough NJ, Farr AL, Randall RJ. 1951.Protein measurement with the Folin 414 phenol reagent. Journal of Biological Chemistry 193: 265-275.

415 Pan D, Mei X. 2010. Antioxidant activity of an exopolysaccharide purified from 416 Lactococcuslactis subsp. lactis 12. Carbohydrate Polymers 80: 908-914.

417 Patel A, Prajapati JB. 2013. Food and Health Applications of Exopolysaccharides produced by 418 Lactic acid Bacteria. LWT - Food Science and Technology 59:732-739.

419 Rai AK, Jini R, Swapna HC, Baskaran V, Sachindra N.M, Bhaskar N. 2011. Application of 420 native lactic acid bacteria for fermentative recovery of lipids and proteins from fish processing 421 waste: Bioactivities of fermentation products Journal of Aquatic Food Products Technology 20: $422 \quad 32-44$. 
423 Sanni AI, Adesulu AT. 2013. Microbiological and physico-chemical changes during 424 fermentation of maize for masa production. African Journal of Microbiology Research 7: 43554254362.

426 Sarwat FQ, Aman SA, Ahmed N. 2008. Production and characterization of a unique dextran 427 from an Indigenous LeuconostocmesenteroidesCMG713. International Journal of Biological 428 Science 4:379-386.

429 Salvucci E, LeBlanc JG, Perez G. 2016. Technological properties of Lactic acid bacteria isolated 430 from rawcereal material. LWT - Food Science and Technology 70: 185-191.

431 Savadogo AC, Ouattara AT, Savadogo PW, Barro N, Ouattara AS, Traore AS. 2004. 432 Identification of exopolysaccharides-producing lactic acid bacteria from Burkina Faso fermented 433 milk samples. African Journal of Biotechnology 3:189-194.

434 Sun Z, Tian Y, Jia M,Pang L, Deng P, Fan K, Liu X, Jia S, Jia L. 2012. Extraction and in vitro 435 antioxidant activity of exopolysaccharide by Pholiota adiposa SX-01.African Journal of 436 Microbiology Research 6:1869-1876.

437 Surayot U, Wang J, Seesuriyachan P, Kuntiya A, Tabarsa M. 2014. Exopolysaccharides from 438 lactic acid bacteria: structural analysis, molecular weight effect on immunomodulation. 439 International Journal of Biological Macromolecules 68:233-240.

440 Tallon R, Bressollier O, Urdaci CM. 2003. Isolation and characterization of two 441 exopolysaccharides produced by Lactobacillus plantarum EP56. Research in Microbiology $442 \quad 154: 705-712$. 
443 Torres-Rodríguez I, Rodríguez-Alegría ME, Miranda-Molina A, Giles-Gómez M, Morales RC,

444 López-Munguía A, Bolívar F, Escalante A. 2014. Screening and characterization of extracellular

445 polysaccharides produced by Leuconostockimchii isolated from traditional fermented pulque

446 beverage. SpringerPlus 3:583.

447 Wang J, Zhang Q, Zhang Z, Li Z. 2008. Antioxidant activity of sulfated polysaccharide fractions 448 extracted from Laminariajaponica. International Journal of Biological Macromolecules 42:127449132.

450 Wang J, Zhao X, Tian Z, Yang Y, Yang Z. 2015.Characterization of an exopolysaccharide 451 produced by Lactobacillus plantarum YW11 isolated from Tibet Kefir. Carbohydrate Polymers $452 \quad 125: 16-25$.

453 Wang Y, Li C, Liu P, Ahmed Z, Xiao P, Bai X. 2010. Physical characterization of 454 exopolysaccharide produced by Lactobacillus plantarum KF5 isolated from Tibet Kefir. 455 Carbohydrate Polymers 82: 895-903.

456 Ye S, Liu, F, Wang J, Wang H, Zhang M. 2012. Antioxidant activities of an exopolysaccharide 457 isolated and purified from marine Pseudomonas PF-6.Carbohydrate Polymers 87:764-770

458 Zajsek K, Gorsek A, Kolar M. 2013. Cultivating conditions effects on kefiran production by the 459 mixed culture of lactic acid bacteria imbedded within kefir grains. Food Chemistry 139: 970460977.

461 Zhang L, Liu C, Li D, Zhao Y, Zhang X, Zeng X, Yang Z, Li S. 2013. Antioxidant activity of an 462 exopolysaccharide isolated from Lactobacillus plantarum C88. International Journal of 463 Biological Macromolecules 54: 270-275. 


\section{Figure 1}

HPLC chromatograms of the EPS samples and standards

(A), EPS-YO175 (B), EPS-OF101 (C). The peaks correspond to glucose (peak 1), xylose (peak

2), galactose (peak 3), fructose (peak 4), rhamnose (peak 5).

$\mathrm{mv}$

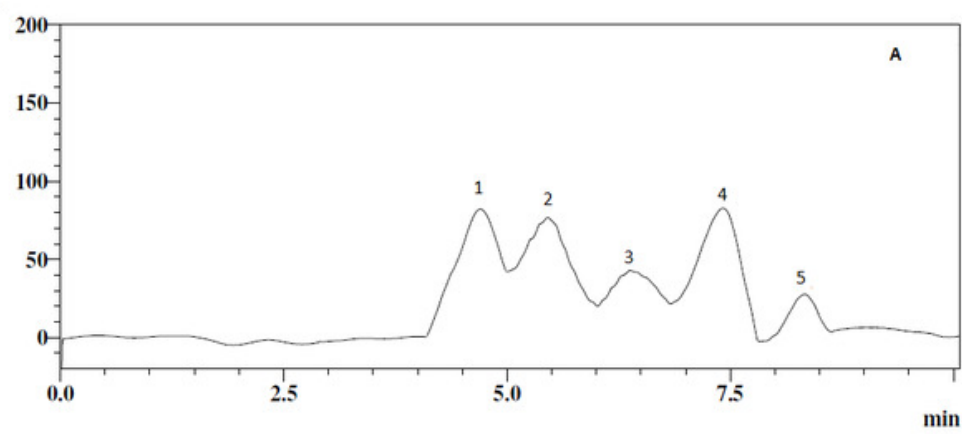

$\mathrm{mV}$

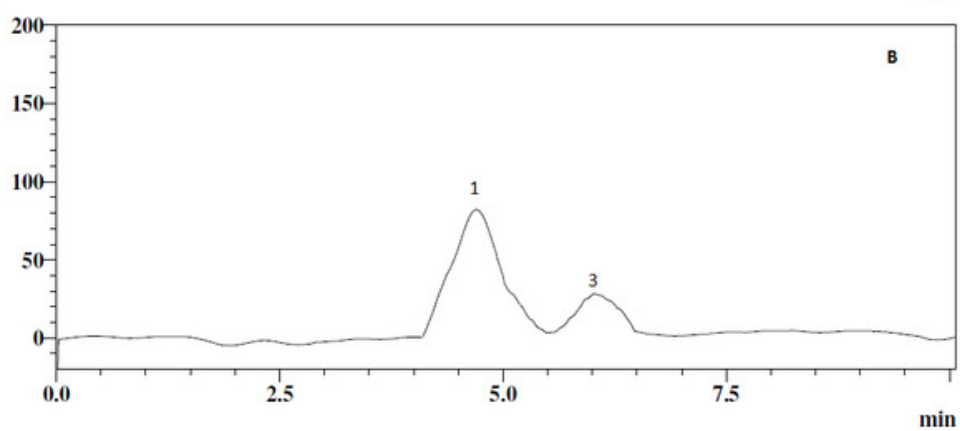

$\mathrm{mV}$

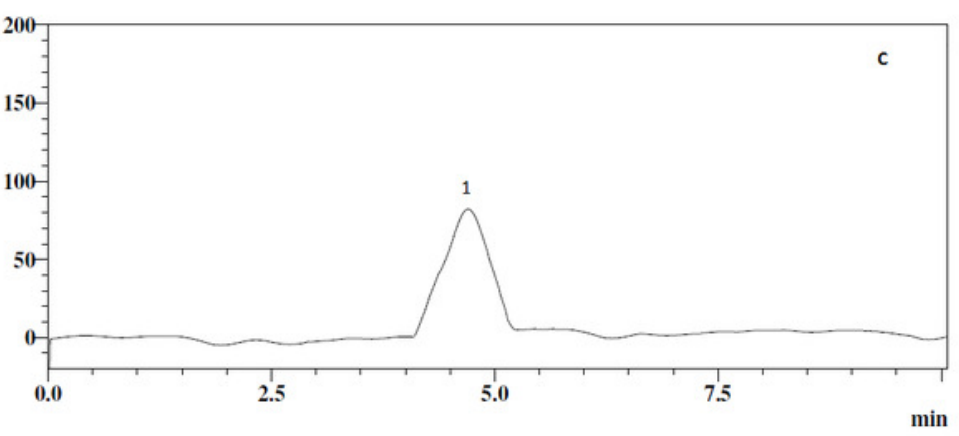


Figure 2

FTIR spectrum of EPS produced

(A) Lactobacillus plantarum Y0175 (B) Lactobacillus plantarum OF101 

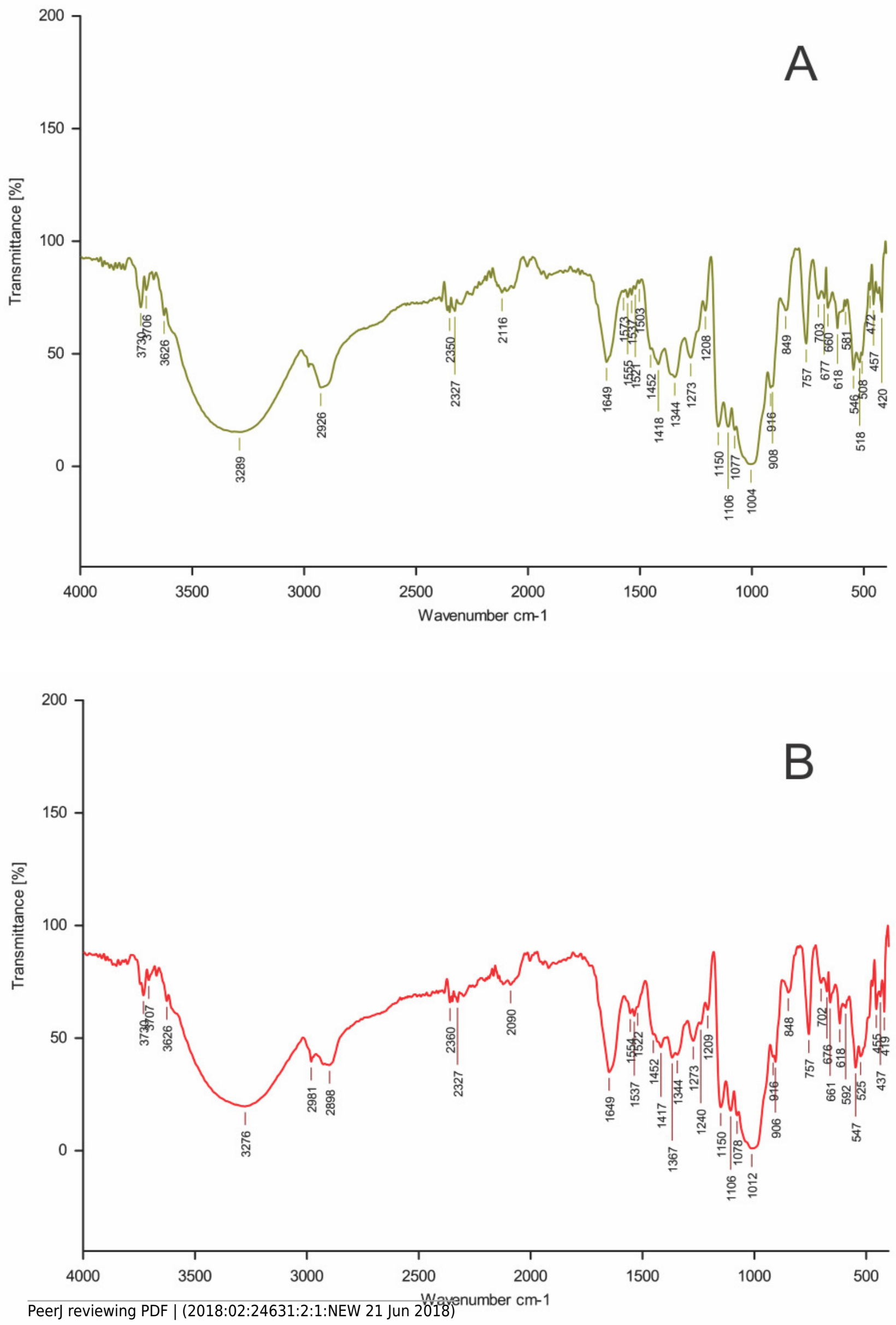
Figure 3

Response surface three-dimensional plots and corresponding contour plots of the three significant variables on EPS yield for Lactobacillus plantarum YO175.

(A) Sucrose concentration and cultivation time (B) $\mathrm{pH}$ and cultivation time (C) $\mathrm{pH}$ and sucrose concentration.
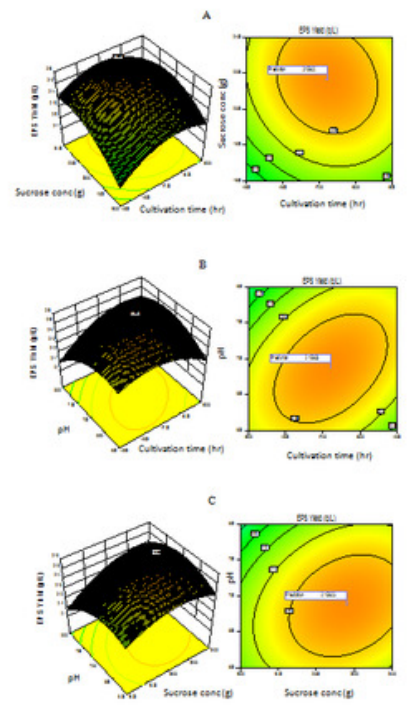


\section{Figure 4}

Response surface three-dimensional plots and corresponding contour plots of the three significant variables on EPS yield for Lactobacillus plantarum OF101

(A) Sucrose concentration and cultivation time (B) $\mathrm{pH}$ and cultivation time (C) $\mathrm{pH}$ and sucrose concentration.
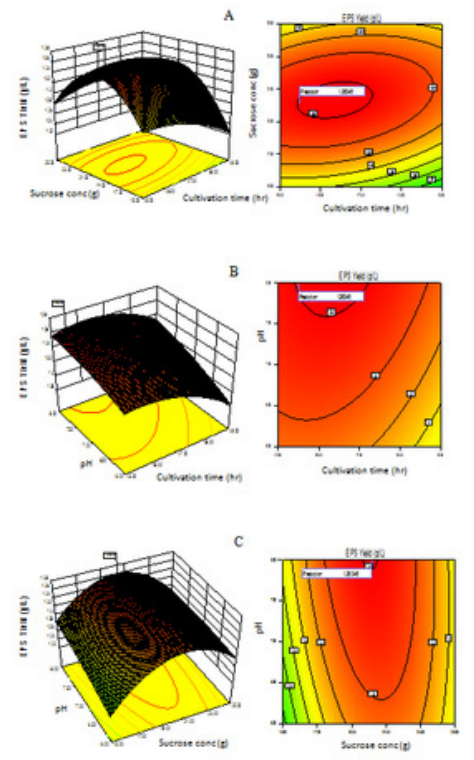


\section{Table $\mathbf{1}$ (on next page)}

Effect of carbon sources, nitrogen sources, and cultivation conditions on exopolysaccharide production

The different carbon sources, organic and inorganic nitrogen and media composition, cultivation conditions were investigated 
1 Table 1: Effect of carbon sources, nitrogen sources, and cultivation conditions on 2 exopolysaccharide production

\begin{tabular}{|c|c|c|}
\hline \multirow{2}{*}{\begin{tabular}{|l} 
Medium sources \\
Carbon sources $(20 \mathrm{~g} / \mathrm{L})$
\end{tabular}} & \multicolumn{2}{|c|}{ EPS yield (g/L) } \\
\hline & EPS-YO175 & EPS-OF101 \\
\hline Glucose & $0.94 \pm 0.10$ & $0.62 \pm 0.44$ \\
\hline Sucrose & $1.59 \pm 0.10$ & $1.07 \pm 0.26$ \\
\hline Lactose & $1.48 \pm 0.14$ & $1.03 \pm 0.17$ \\
\hline Galactose & $0.87 \pm 0.26$ & $0.41 \pm 0.26$ \\
\hline \multicolumn{3}{|c|}{ Sucrose concentrations $(\mathrm{g} / \mathrm{L})$} \\
\hline 10 & $1.13 \pm 0.20$ & $0.90 \pm 0.62$ \\
\hline 20 & $1.64 \pm 0.44$ & $1.05 \pm 0.44$ \\
\hline 30 & $1.52 \pm 0.26$ & $0.71 \pm 0.56$ \\
\hline 40 & $1.45 \pm 0.75$ & $0.62 \pm 0.17$ \\
\hline 50 & $1.10 \pm 0.00$ & $0.36 \pm 0.10$ \\
\hline \multicolumn{3}{|l|}{ Organic nitrogen $(25 \mathrm{~g} / \mathrm{L})$} \\
\hline Yeast extract & $1.63 \pm 0.07$ & $1.01 \pm 0.11$ \\
\hline Beef extract & $1.15 \pm 0.22$ & $0.82 \pm 0.10$ \\
\hline Tryptone & $1.48 \pm 0.31$ & $0.83 \pm 0.24$ \\
\hline Peptone & $1.61 \pm 0.01$ & $0.77 \pm 0.20$ \\
\hline \multicolumn{3}{|l|}{ Inorganic nitrogen $(2 \mathrm{~g} / \mathrm{L})$} \\
\hline Ammonium sulphate & $1.56 \pm 0.10$ & $1.00 \pm 0.00$ \\
\hline Ammonium nitrate & $1.51 \pm 0.00$ & $0.80 \pm 0.00$ \\
\hline Ammonium chloride & $1.48 \pm 0.21$ & $0.71 \pm 0.10$ \\
\hline Tri-ammonium citrate & $1.37 \pm 0.32$ & $0.75 \pm 0.12$ \\
\hline Sodium nitrite & $1.30 \pm 0.10$ & $0.68 \pm 0.26$ \\
\hline Potassium nitrate & $1.15 \pm 0.24$ & $0.72 \pm 0.18$ \\
\hline \multicolumn{3}{|l|}{ Temperature $\left({ }^{\circ} \mathrm{C}\right)$} \\
\hline 20 & $0.53 \pm 0.20$ & $0.20 \pm 0.01$ \\
\hline 25 & $0.77 \pm 0.01$ & $0.31 \pm 0.08$ \\
\hline 30 & $1.56 \pm 0.10$ & $1.03 \pm 0.11$ \\
\hline 37 & $1.50 \pm 0.18$ & $0.80 \pm 0.00$ \\
\hline 45 & $0.46 \pm 0.24$ & $0.10 \pm 0.10$ \\
\hline \multicolumn{3}{|l|}{ Cultivation time (hr) } \\
\hline 12 & $0.30 \pm 0.06$ & $0.10 \pm 0.04$ \\
\hline 24 & $1.70 \pm 0.08$ & $0.76 \pm 0.10$ \\
\hline 36 & $1.66 \pm 0.24$ & $1.00 \pm 0.12$ \\
\hline 48 & $1.68 \pm 0.20$ & $1.08 \pm 022$ \\
\hline 60 & $1.50 \pm 0.10$ & $1.02 \pm 0.24$ \\
\hline 72 & $1.38 \pm 0.07$ & $0.72 \pm 0.11$ \\
\hline 84 & $1.17 \pm 0.04$ & $0.66 \pm 0.22$ \\
\hline 96 & $1.00 \pm 0.30$ & $0.60 \pm 0.32$ \\
\hline \multicolumn{3}{|l|}{ pH } \\
\hline 6.0 & $1.51 \pm 0.11$ & $0.65 \pm 0.01$ \\
\hline 6.5 & $1.60 \pm 0.00$ & $1.01 \pm 0.01$ \\
\hline 7.0 & $1.72 \pm 0.24$ & $1.10 \pm 0.02$ \\
\hline 8.0 & $1.50 \pm 0.33$ & $0.82 \pm 0.07$ \\
\hline
\end{tabular}




\section{Table 2 (on next page)}

The central composite experimental design matrix showing the predicted and experimental values of exopolysaccharides from Lactobacillus plantarum Y0175 and OF101

The CCD of the EPS samples 
1 Table 2A: The central composite experimental design matrix showing the predicted and

\begin{tabular}{cccccc}
2 & \multicolumn{2}{c}{ experimental values of exopolysaccharide } & from Lactobacillus plantarum YO175 \\
\hline Run & $\begin{array}{c}\mathbf{A} \\
\text { Cultivation } \\
\text { time (hr) }\end{array}$ & $\begin{array}{c}\text { B } \\
\text { Sucrose } \\
\text { concentration (g) }\end{array}$ & $\begin{array}{c}\mathbf{C} \\
\mathbf{p H}\end{array}$ & $\begin{array}{c}\text { EPS Yield (g/L) } \\
\text { Experimental (E1) }\end{array}$ & Predicted \\
\hline 1 & 45.48 & 24.00 & 6.99 & 1.28 & 1.22 \\
2 & 46.80 & 23.09 & 6.87 & 1.29 & 1.25 \\
3 & 47.95 & 21.09 & 6.51 & 1.30 & 1.31 \\
4 & 46.18 & 20.34 & 7.50 & 1.34 & 1.32 \\
5 & 45.74 & 20.00 & 6.42 & 1.35 & 1.33 \\
6 & 45.96 & 19.92 & 7.44 & 1.32 & 1.34 \\
7 & 45.93 & 20.34 & 8.00 & 1.31 & 1.30 \\
8 & 46.65 & 20.64 & 7.71 & 1.33 & 1.31 \\
9 & 46.05 & 19.62 & 6.94 & 1.34 & 1.28 \\
10 & 48.50 & 23.00 & 7.40 & 1.36 & 1.38 \\
11 & 45.89 & 19.88 & 6.74 & 1.32 & 1.31 \\
12 & 45.86 & 16.50 & 7.97 & 1.28 & 1.28 \\
13 & 45.67 & 20.11 & 7.80 & 1.26 & 1.31 \\
14 & 46.18 & 20.13 & 7.88 & 1.30 & 1.32 \\
15 & 46.82 & 20.29 & 8.01 & 1.33 & 1.34 \\
16 & 46.44 & 20.85 & 7.73 & 1.35 & 1.33 \\
17 & 45.94 & 20.04 & 7.00 & 1.30 & 1.27 \\
18 & 46.03 & 19.87 & 7.98 & 1.29 & 1.30 \\
19 & 45.81 & 19.71 & 7.90 & 1.27 & 1.31 \\
20 & 49.14 & 20.26 & 6.86 & 1.31 & 1.32 \\
\hline 3 & & & &
\end{tabular}

3 4 5 6 7 8 9 10 11 12 13 14 15 16 17 18 19 20 21 22 23 
24 Table 2B: The central composite experimental design matrix showing the predicted and actual

\begin{tabular}{cccccc}
25 & \multicolumn{2}{c}{ values of exopolysaccharide from Lactobacillus plantarum OF101 } \\
\hline Run & $\begin{array}{c}\text { A } \\
\text { Cultivation } \\
\text { time (hr) }\end{array}$ & $\begin{array}{c}\text { B } \\
\text { Sucrose } \\
\text { concentration (g) }\end{array}$ & $\begin{array}{c}\mathbf{C} \\
\mathbf{p H}\end{array}$ & $\begin{array}{c}\text { EPS Yield (g/L) } \\
\text { Experimental (E1) }\end{array}$ & Predicted \\
\hline 1 & 47.00 & 20.00 & 7.00 & 2.17 & 2.16 \\
2 & 49.00 & 16.00 & 8.00 & 2.12 & 2.10 \\
3 & 49.00 & 24.00 & 8.00 & 2.09 & 2.10 \\
4 & 49.00 & 24.00 & 6.00 & 2.06 & 2.10 \\
5 & 45.00 & 24.00 & 6.00 & 2.04 & 2.05 \\
6 & 49.00 & 16.00 & 8.00 & 2.10 & 2.12 \\
7 & 45.00 & 16.00 & 7.76 & 2.08 & 2.14 \\
8 & 45.00 & 16.00 & 6.70 & 2.06 & 2.10 \\
9 & 45.29 & 24.00 & 7.47 & 2.13 & 2.14 \\
10 & 45.84 & 18.92 & 6.98 & 2.14 & 2.15 \\
11 & 47.64 & 23.76 & 7.72 & 2.14 & 2.10 \\
12 & 45.78 & 21.28 & 6.60 & 2.15 & 2.06 \\
13 & 48.16 & 18.03 & 7.24 & 2.11 & 2.10 \\
14 & 47.70 & 23.50 & 7.80 & 2.18 & 2.19 \\
15 & 47.65 & 17.10 & 7.81 & 2.13 & 2.15 \\
16 & 47.10 & 23.34 & 7.40 & 2.12 & 2.10 \\
17 & 47.16 & 22.89 & 7.95 & 2.15 & 2.15 \\
18 & 47.67 & 19.24 & 7.94 & 2.12 & 2.10 \\
19 & 45.11 & 17.10 & 6.70 & 2.09 & 2.08 \\
20 & 47.88 & 23.34 & 6.42 & 2.04 & 2.00 \\
\hline
\end{tabular}

26

27

28

29 


\section{Table 3(on next page)}

Analysis of Variance (ANOVA) of quadratic model for production of exopolysaccharide in Lactobacillus plantarum Y0175 and OF101

The ANOVA table generated from the RSM analysis 
1 Table 3A: Analysis of Variance (ANOVA) of quadratic model for production of 2 exopolysaccharide in Lactobacillus plantarum YO175

\begin{tabular}{lllllll}
\hline Source & $\begin{array}{l}\text { Sum of } \\
\text { Squares }\end{array}$ & df & $\begin{array}{l}\text { Mean } \\
\text { Square }\end{array}$ & $\begin{array}{l}\text { F } \\
\text { Value }\end{array}$ & $\begin{array}{l}\text { p-value } \\
\text { Prob }>\text { F }\end{array}$ & \\
\hline Model & 9.905 & 9 & 7.21 & 5.88 & 0.0053 & Significant \\
A-Cultivation & 4.740 & 1 & 4.740 & 2.53 & 0.1425 & \\
time & & & & & & \\
B-Sucrose conc. & 1.511 & 1 & 1.511 & 8.08 & 0.0175 & \\
C-pH & 7.389 & 1 & 7.389 & 3.95 & 0.0749 & \\
AB & 1.125 & 1 & 1.125 & 0.60 & 0.4559 & \\
AC & 1.013 & 1 & 1.013 & 5.41 & 0.0423 & \\
BC & 3.125 & 1 & 3.125 & 1.67 & 0.2252 & \\
$\mathrm{~A}^{2}$ & 2.500 & 1 & 2.500 & 13.37 & 0.0044 & \\
$\mathrm{~B}^{2}$ & 1.870 & 1 & 1.870 & 10.02 & 0.0101 & \\
$\mathrm{C}^{2}$ & 3.369 & 1 & 3.369 & 13.37 & 0.0044 & \\
Residual & 1.870 & 10 & 1.870 & & & \\
Lack of Fit & 3.369 & 5 & 3.369 & 0.22 & 0.9391 & not significant \\
Pure Error & 1.533 & 5 & 1.04 & & & \\
Cor Total & 0.012 & 19 & & & & \\
\hline
\end{tabular}
$\mathrm{R}$-Squared $=0.8412$; Adequate Precision $=8.558$.

4

5

6

7

8

9

10

11

12

13

14

15

16

17

18

19

20

21

22

23

24

25

26

27

28 


\begin{tabular}{|c|c|c|c|c|c|c|}
\hline Source & $\begin{array}{l}\text { Sum of } \\
\text { Squares }\end{array}$ & Df & $\begin{array}{l}\text { Mean } \\
\text { Square }\end{array}$ & $\begin{array}{l}\text { F } \\
\text { Value }\end{array}$ & $\begin{array}{l}\text { p-value } \\
\text { Prob }>\text { F }\end{array}$ & \\
\hline Model & 0.10 & 9 & 0.04 & 8.88 & 0.0010 & Significant \\
\hline $\begin{array}{l}\text { A-Cultivation } \\
\text { time }\end{array}$ & 4.663 & 1 & 4.663 & 3.65 & 0.0852 & \\
\hline B-Sucrose conc. & 0.010 & 1 & 0.010 & 7.88 & 0.0186 & \\
\hline C-pH & 4.967 & 1 & 4.967 & 3.89 & 0.0770 & \\
\hline $\mathrm{AB}$ & 2.813 & 1 & 2.813 & 2.20 & 0.1688 & \\
\hline $\mathrm{AC}$ & 3.125 & 1 & 3.125 & 0.24 & 0.6317 & \\
\hline $\mathrm{BC}$ & 1.012 & 1 & 1.012 & 0.79 & 0.3944 & \\
\hline $\mathrm{A}^{2}$ & 3.982 & 1 & 3.982 & 3.12 & 0.1080 & \\
\hline$B^{2}$ & 0.078 & 1 & 0.078 & 61.20 & $<0.0001$ & \\
\hline $\mathrm{C}^{2}$ & 0.13 & 1 & 0.13 & 0.27 & 0.6167 & \\
\hline Residual & 0.013 & 10 & 0.013 & & & \\
\hline Lack of Fit & 0.013 & 6 & 0.013 & 70.35 & 0.6252 & $\begin{array}{l}\text { Not- } \\
\text { significant }\end{array}$ \\
\hline Pure Error & 1.200 & 4 & 0.80 & & & \\
\hline Cor Total & 0.11 & 19 & & & & \\
\hline
\end{tabular}

Table 3B: Analysis of Variance (ANOVA) of quadratic model for production of exopolysaccharide in Lactobacillus plantarum OF101

R-Squared $=0.8888 ;$ Adequate Precision $=10.789$

33

34

35

36

37

38

39

40

41

42

43 


\section{Table 4(on next page)}

In vitro antioxidant activities of the exopolysaccharides from L. plantarum YO175 and OF101

The antioxidant activities of the EPS samples 
3

\section{Concentrations (mg/mL)}

0.5

1.0

1.5

2.0

2.5

3.0

3.5

4.0

0.5

1.0

1.5

2.0

2.5

3.0

3.5

4.0

0.5

1.0

1.5

2.0

2.5

3.0

3.5

4.0

0.5

1.0

1.5

2.0

2.5

3.0

3.5

OF101

.

(2)

56

(1)

82

5

$37.9 \pm 0.36^{\mathrm{b}}$

$51.3 \pm 0.70^{\mathrm{b}}$

$57.4 \pm 0.80^{\mathrm{b}}$

$64.3 \pm 0.53^{\mathrm{b}}$

$69.1 \pm 1.05^{\mathrm{b}}$

$74.2 \pm 0.35^{b}$

$80.4 \pm 0.53^{\mathrm{b}}$

$83.1 \pm 0.17^{\mathrm{b}}$

$38.7 \pm 0.21^{\mathrm{c}}$

$47.0 \pm 0.20^{\mathrm{c}}$

$56.1 \pm 0.00^{\mathrm{c}}$

$64.7 \pm 1.47^{\mathrm{c}}$

$72.1 \pm 0.90^{\mathrm{c}}$

$78.3 \pm 1.74^{\mathrm{c}}$

$82.1 \pm 1.23^{\mathrm{c}}$

DPPH scavenging activity (\%)

EPS-YO175 $\quad$ EPS-OF101

$22.3 \pm 0.79^{b}$

$18.9 \pm 0.66^{\mathrm{a}}$

$28.3 \pm 0.82^{\mathrm{b}}$

$21.3 \pm 0.76^{\mathrm{a}}$

$35.3 \pm 0.30^{\mathrm{b}}$

$27.4 \pm 1.83^{\mathrm{a}}$

$39.1 \pm 0.23^{\mathrm{b}}$

$32.8 \pm 0.17^{\mathrm{a}}$

$46.5 \pm 0.95^{b}$

$40.8 \pm 1.56^{\mathrm{a}}$

$50.7 \pm 0.44^{\mathrm{b}}$

$47.6 \pm 0.56^{\mathrm{a}}$

$54.0 \pm 0.00^{\mathrm{b}}$

$49.8 \pm 0.20^{\mathrm{a}}$

$56.9 \pm 1.77^{\mathrm{b}}$

$51.3 \pm 0.35^{\mathrm{a}}$

Superoxide scavenging activity (\%)

$43.2 \pm 0.53^{\mathrm{c}}$

$23.0 \pm 0.00^{\mathrm{a}}$

$55.7 \pm 0.36^{\mathrm{c}}$

$27.8 \pm 0.35^{\mathrm{a}}$

$62.1 \pm 0.56^{\mathrm{c}}$

$31.4 \pm 0.35^{\mathrm{a}}$

$69.8 \pm 0.79^{c}$

$35.7 \pm 0.70^{\mathrm{a}}$

$77.6 \pm 0.70^{\mathrm{c}}$

$38.9 \pm 1.08^{\mathrm{a}}$

$82.6 \pm 0.56^{\mathrm{c}}$

$41.8 \pm 0.20^{\mathrm{a}}$

$86.3 \pm 0.70^{\mathrm{c}}$

$42.7 \pm 0.45^{\mathrm{a}}$

$89.4 \pm 0.35^{\mathrm{c}}$

$45.2 \pm 0.20^{\mathrm{a}}$

\section{Reducing power activity (Abs 700nm)}

$0.33 \pm 0.62^{\mathrm{b}}$
$0.55 \pm 0.00^{\mathrm{b}}$
$0.67 \pm 0.04^{\mathrm{b}}$
$0.71 \pm 0.04^{\mathrm{b}}$
$0.75 \pm 0.02^{\mathrm{b}}$
$0.82 \pm 0.03^{\mathrm{c}}$
$0.87 \pm 0.11^{\mathrm{b}}$
$0.91 \pm 0.03^{\mathrm{c}}$

$0.17 \pm 0.02^{\mathrm{a}}$

$0.11 \pm 0.00^{\mathrm{a}}$

\section{Hydroxyl radical scavenging activity (\%)}

$\begin{array}{lll}38.7 \pm 0.69^{\mathrm{c}} & 26.8 \pm 0.70^{\mathrm{b}} & 22.0 \pm 0.00^{\mathrm{a}} \\ 49.7 \pm 0.61^{\mathrm{c}} & 37.6 \pm 0.36^{\mathrm{b}} & 27.0 \pm 0.35^{\mathrm{a}} \\ 57.4 \pm 0.87^{\mathrm{c}} & 41.3 \pm 0.61^{\mathrm{b}} & 31.2 \pm 1.27^{\mathrm{a}} \\ 64.3 \pm 0.61^{\mathrm{c}} & 45.8 \pm 0.53^{\mathrm{b}} & 37.9 \pm 0.10^{\mathrm{a}} \\ 69.1 \pm 0.27^{\mathrm{c}} & 53.2 \pm 1.59^{\mathrm{b}} & 44.7 \pm 0.62^{\mathrm{a}} \\ 74.2 \pm 0.82^{\mathrm{c}} & 57.1 \pm 0.17^{\mathrm{b}} & 49.2 \pm 0.82^{\mathrm{a}} \\ 80.4 \pm 0.60^{\mathrm{c}} & 62.3 \pm 0.70^{\mathrm{b}} & 50.1 \pm 0.17^{\mathrm{a}} \\ 83.1 \pm 1.39^{\mathrm{c}} & 66.0 \pm 0.00^{\mathrm{b}} & 52.3 \pm 0.30^{\mathrm{a}}\end{array}$

Values are means of three independent experiments (mean \pm SD). ${ }^{a, b, c}$ Means in the same column with different superscript letters represent significant difference $(\mathrm{P}<0.05)$ by Duncan's post hoc comparisons. 